\title{
Vaskulêre endoteel - die brandpunt teen trombose
}

Sedert 1856 toe Rudolf Carl Virchow, hoogleraar aan die Charité in Berlyn, sy beroemde drietal uitgespel het, word endoteelbesering, vertraagde bloedvloei en veranderinge in die fisies-chemiese samestelling van die bloed, wêreldwyd aanvaar as die sleutel tot die patogenese van veneuse tromboemboliese siekte. ${ }^{1}$ Waar Virchow die hooffunksie van veneuse endoteel gesien het bloot as 'n meganiese vloeioppervlakte, word die endoteelsel vandag beskou as een van die ingeboude meganismes teen intravaskulêre trombogenese. Verskeie belangrike funksies word aan endoteel toegeskryf, nl. elektrostatiese afwering deur ' $n$ negatief gelaaide oppervlakte, bedekking van subendoteliale kollageen, die aktivering van plasminogeen en die sintese van prostasiklien, heparan en opsoniese fibronektien. ${ }^{2}$ Normale intakte endoteel is nie-trombogeen. Wanneer die intima egter deur immuunkomplekse, endotoksien, virusse en chemiese of fisiese agense beskadig word, word subendoteliale kollageen blootgelê - 'n kragtige plaatjieverklompingsagens en 'n direkte aktiveerder van faktor XII, wat die beginpunt van die intrinsieke stelsel van die bloedstollingskaskade verteenwoordig. Die stroping van endoteelselle, skeuring van die basaalmembraan, die blootstelling van kollageenvesels en die vorming van die primêre bloedplaatjietrombus kan geredelik deur middel van skanderingselektronmikroskopie van die lumenale oppervlakte aangetoon word.

In die opruiming van gevormde intravaskulêre trombus speel die endoteelsel ook 'n sleutelrol. Veneuse endoteel is ' $n$ aktiveerder van plasminogeen, die voorloper van plasmien wat fibrienvorming beperk. Die vrylating van ' $n$ aktiveerder kan vandag geredelik aangetoon word deur 'n gevestigde histochemiese metode. Kwantifisering van die sogenaamde fibronolitiese outograaf is ' $n$ herhaalbare bepaling van ' $n$ grondliggende onderdeel van die fibrinolitiese verdedigingsmeganisme. ${ }^{3}$

Lae plasma fibrinolitiese aktiwiteit as gevolg van 'n gebrekkige vrylating van die plasminogeenaktiveerder, word vandag beskou as 'n belangrike risikofaktor vir diep veneuse trombose van "onbekende" oorsprong. ${ }^{4}$

Prostasiklien, wat die kleefbaarheid en sameklomping van plaatjies verminder, ook as die kragtigste vaatverwyder bekend, word in die endoteelsel uit die essensiële vetsuur, aragidoonsuur, gesintetiseer. ${ }^{5}$ Aragidoonsuur word deur middel van die ensiem sikliese oksigenase omvorm in sikliese endoperoksiede. Verdere metabolisme word bepaal deur die spesifisiteit van 'n sintetase, wat in die geval van die endoteelsel sal lei tot die sintese van prostasiklien. Andersyds word die endoperoksiede in die bloedplaatjie omvorm in tromboksaan $\mathbf{A}_{2}$ met geheel en al die teenoorgestelde effek, nl. vaatvernouing en die bevordering van plaatjieklewerigheid en verklomping. Uit dieselfde substraat vorm die endoteelsel dus 'n produk wat trombose bekamp; uit dieselfde substraat vorm die bloedplaatjie andersyds 'n stof wat onteenseglik trombose bevorder.

Hierdie bevindings het grondliggende terapeutiese implikasies wat tans naarstiglik nagevors word. Die biochemiese interaksie tussen endoteelselle en bloedplaatjies kan by die gemeenskaplike endoperoksiedkruispad farmakologies gemanipuleer word deur sikliese oksigenaseremmers, bv. aspirien. Die differensiële effek kan teweeg gebring word deur die dosis van aspirien te varieer. By lae dosering van aspirien word tromboksaansintese onderdruk; by hoë dosering, andersyds, word prostasikliensintese ook geraak. Alhoewel die optimumdosis van aspirien as ' $n$ tromboseweringsmiddel nog onder oorweging is, is daar in die huidige staat van ons kennis wel steun vir die toediening van $3,5 \mathrm{mg} / \mathrm{kg}$ aspirien met tussenposes van drie dae. ${ }^{6}$ Insgelyks word daar ook naarstiglik gesoek na 'n middel wat endogene fibrinolise deur die endoteelsel sal stimuleer. Sekere steroïede met die alkielradikaal by die 17-alfaposisie, bv. etielestrenol, hou aansienlike belofte in.

Alhoewel Virchow se grondbeginsels sekerlik die toets van die tyd trotseer het, is daar nou meer as een en 'n kwart eeu later groeipunte binne hierdie raamwerk wat sekerlik aan die versiende vader van sellulêre siektekunde veel vreugde sou besorg.

\section{VERWYSINGS}

1. Virchow, R. (1856). Gesammelte Abhandl. zur Wissenschaft. Med. von Rud. Virchow (Frankfurt Meidinger) p. 219.

2. Hirsch, J., Genton, E. \& Hull, R. (1981). Venous thromboembolism (New York, Grune \& Stratton).

3. Todd, A.S. (1959). The histological localisation of fibrinolysin activator. J. Path. Bact, 78.

4. Pandolfi, M., Isacson, S. \& Nilson, I.M. (1969). Low fibrinolytic activity in the walls of veins in patients with thrombosis. Acta Med. Scand., 186, 1-5.

5. Moncada, S. \& Vane, J.R. (1977). In Biochemical aspects of prostaglandins and thromboxanes, Khanasch, N. \& Fried, J. eds. (Academic Press) pp. 155-177.

6. Masotti, G., Poggesi, L., Galanti, G., Abbate, R. \& Neri Serneri, G.G. (1979). Differential inhibition of prostacyclin production and platelet aggregation by aspirin. The Lancet, ii, 1213-1216.

\section{ENKELE WOORDVERKLARINGS}

Endoteel: Enkele laag selle wat die bloedvate uitvoer.

Patogenese: Wyse waarop 'n siekte ontwikkel.

Veneus (m.b.t. vena): Die are wat die bloed terugvoer vanaf die weefsels na die hart.

Trombo-emboliese siekte: 'n Toestand gekenmerk deur die vorming van bloedklonte in die are. 'n Bloedklontfragment wat losraak, sirkuleer en elders in die bloedsomloop vassteek en obstruksie veroorsaak staan bekend as 'n embolus.

Subendoteliaal: Diep tot die endoteel. 
Kollageen: 'n Proteïen. Die hoof organiese bestanddeel van bindweefsel.

Plasminogeen: Die onaktiewe voorloper van plasmien, die proteolitiese ensiem van plasma wat in staat is om bloedstolsels in bloedvate op te los.

Prostasiklien ( $\left.\mathrm{PGI}_{2}\right)$ : Behoort aan 'n groep hormoonagtige stowwe, die prostaglandienes (onversadigde hidroksievetsure). Prostasiklien werk adhesie van plaatjies aan die vaatwand en plaatjie-aggregasie (verklomping) teë.

Heparan: Heparienagtige stof wat deur endoteelselle afgeskei word wat bloedstolling teëwerk.

Opsonien: 'n Stof wat noodsaaklik is vir die opruimselle van die liggaam om kieme te verorber.

Fibronektien: 'n alfa-2-glikoproteien in sirkulerende plasma wat ageer as 'n opsonien.

Intima: Die heel binneste van die drie lae van 'n bloedvat. Hierdie laag bestaan uit die endoteelselle wat rus op die basaalmembraan. Lg. word op sy beurt omring deur die kollageen bindweefselvesels.
Fibrien: Proteiennetwerk wat gevorm word wanneer bloed stol - die belangrikste deel van die bloedklont.

Histochemie: Mikroskopiese studie van die chemie van weefsels d.m.v. reagense wat sigbare reaksies voortbring.

Fibrinolise: Die ensiematiese lise van fibrien. (Stolselafbraak).

Aragidoonsuur: 'n Onversadigde hidroksieversuur wat deur ' $n$ ensiem (waarskynlik fosfolipase $A_{2}$ ), vanaf weefselfosfolipiede vrygestel word.

Sikliese oksigenase: 'n Ensiem wat die vetsure tot endoperoksiede oksideer. Endoperoksiede word op hulle beurt na tromboksane, prostasikliene of prostaglandiene omvorm.

R.C. Franz

Departement Chirurgie, Fakulteit van Geneeskunde, Universiteit van Pretoria, Posbus 667, Pretoria 0001 